\title{
Tangier's Current Re-Configurations from a Multi-Scale Spatial Perspective: Emerging Transregional Ties and Local Repercussions
}

\section{Steffen Wippel}

\section{Introduction: Local and (Trans-)Regional Re-Configurations}

The northern Moroccan urban agglomeration of Tangier has experienced rapid, spectacular changes over the last decade, mainly as a result of urban megaprojects and the expansion of transport infrastructure. Not only has this effectuated important local transformations, but it also holds wider repercussions and fits within larger re-configurations, each playing out on several spatial scales. The enhancement of far-reaching regional and transregional links is an important aspect of this.

This chapter presents a few insights from a research project within the research network "Re-Configurations: History, Remembrance, and Transformation Processes in the Middle East and North Africa" at Philipps-Universität Marburg from late 2015 to early 2019. Accordingly, the chapter views "re-configurations" as complex, varied, and open-ended transformation processes, which are not necessarily purposive $\mathrm{e}^{1}$ and are sometimes fragmentary, inconsistent, and conflictual. These processes are indicative not only of changes to one particular element in a given setting, but in fact reflect entire constellations of actors, structures, spaces, and flows. In particular, I will endeavor to show the historicity of current developments that go beyond the widely observed and analyzed ruptures in the aftermath of the 2011 "Arab Spring." Concurrently, the aforementioned project integrated the research field on "transregional entanglements"

S. Wippel $(\bowtie)$

Berlin, Germany

e-mail: steffen.wippel@t-online.de

CC The Author(s) 2021

R. Ouaissa et al. (eds.), Re-Configurations, Politik und Gesellschaft des Nahen

Ostens, https://doi.org/10.1007/978-3-658-31160-5_6 
during the network's first stage, then merged into the analytical axis on "space" in the second stage. This perspective recognized that ongoing re-configurations also encompass important spatial aspects. Just as the entire network sought to challenge prevalent research practices, this particular study set out to scrutinize conventional spatial and scalar preconceptions in established systematic disciplines and area studies by understanding space and scale as historically produced and continuously changing geographies and by looking beyond established containers, such as the "MENA region" or the "national" methodological approach.

Hence, this chapter will adopt a predominantly spatial perspective on important current re-configurations of a specific city and the development of (trans)regional entanglements emanating from this place; more generalized results of the same research have been published in a separate edited volume (Wippel and Fischer-Tahir 2018). The chapter begins with a brief overview of Tangier's development and the current projects. It will then shed light on five aspects related to the ideas described above, which transcend the purely local dimension: actors, programs, entanglements, positionings of the city, and, in a return to the local, the city's fragmentations. The conclusion will present a more conceptual outlook and sum up the findings.

\section{Contemporary Mega-Projects Re-Configuring Tangier}

In the distant past, Tangier was already an important transshipment center connecting trans-Saharan (overland) and trans-Mediterranean (maritime) trade. In the nineteenth century, the city increasingly came under international administration and evolved into Morocco's main trading port (Stuart 1955). Major European shipping lines began to call at Tangier on their way to Africa, Latin America, and even the Dutch East Indies (Fig. 1). During this period, the city prospered, and its population was a cosmopolitan mixture of Moroccan Muslims and Jews, Spaniards, and other Europeans. After Moroccan independence, King Hassan II deliberately neglected Morocco's northern provinces for political reasons. Tangier stagnated and lost its exceptional position. Only when Mohamed VI ascended to the throne in 1999 did existing plans and new programs begin to be physically implemented. Since then, new economic and transport infrastructure has been established, and Tangier has undergone a considerable urban restructuring process (Figs. 2 and 6). ${ }^{2}$

The most visible result was the 2007 opening of the enormous Tanger-Méditerranée Tangier-Mediterranean container port east of the city, 


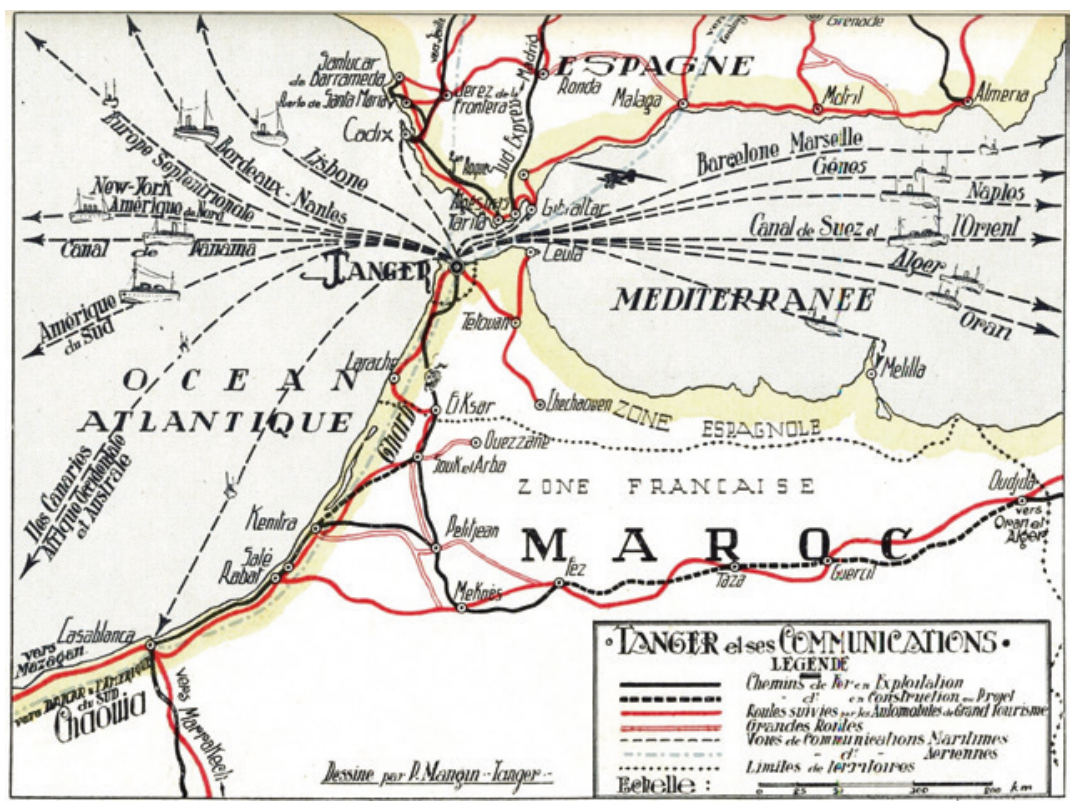

Fig. 1 Tangier as a Transport Hub during the International Zone Period (1923-1956); Source: Propaganda and Tourism Section of the Tangier Zone. 1929. Tangier: Winter Resort, Summer Resort. Paris: Horizons de France, 32. Retrieved from http:/interactiveworlds.blogspot.com/2006/12, 16 April 2019.

which has the capacity to process three million standard containers a year (see also Barthel and Planel 2010; Ducruet et al. 2011; Mareï 2012). It is currently being expanded to more than triple its capacity. ${ }^{3}$ The TangerMed platform also encompasses cargo, oil, vehicle and passenger terminals, as well as free trade zones, logistical areas, industrial parks, and an important "automotive city" scattered across the Tangier Peninsula. The second large project, Tanger Ville Tangier City, is focused on transforming the old inner-city port area into a luxurious tourism, leisure, and consumer-oriented waterfront (cf. also Benabad 2012). This is supplemented by the Tanger Métropole Tangier Metropolis plan, which supports local efforts to enhance urban social, cultural, and environmental infrastructure. The most recent large-scale project is a gigantic technological, industrial, and residential complex called Cité Mohammed VI TangerTech. Likewise, other new towns on the city's southern periphery are expected to help improve the pressing housing shortage. 

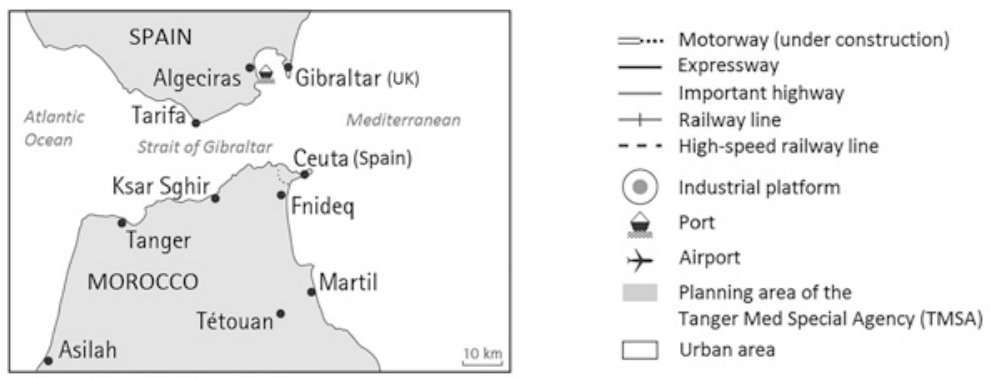

Kartographie: Sabrina Henschel, 2017

Tan

Urban area

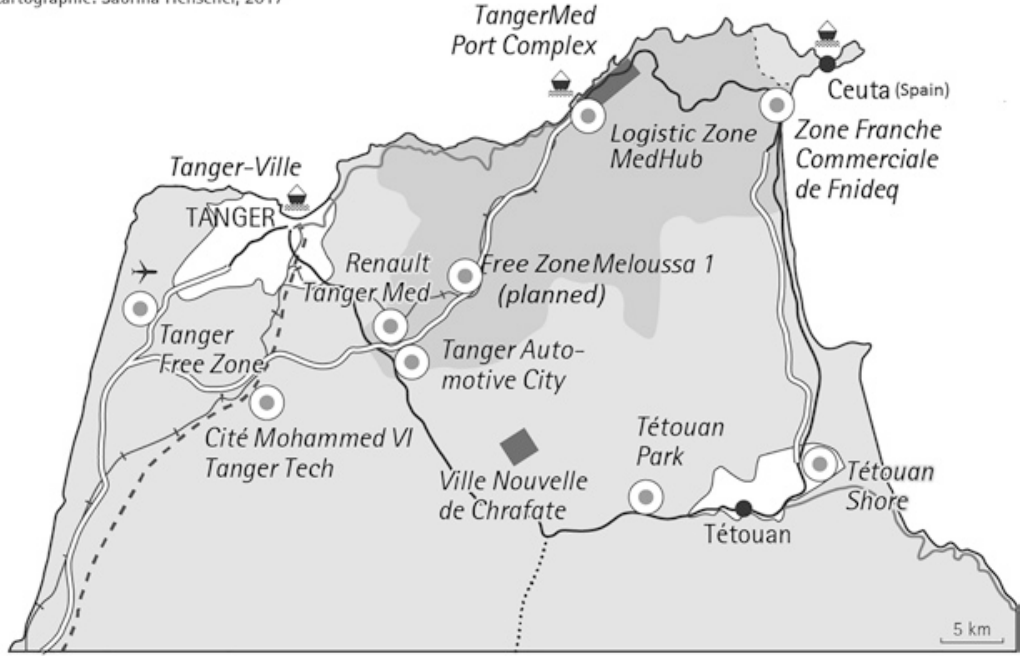

Fig. 2 Major Projects on the Tangier Peninsula since the Late 2000s; Concept and English legend: Steffen Wippel; cartography: Sabrina Henschel 2017.

These major projects have been supplemented by the construction of numerous integrated tourism complexes and luxury hotels along the Bay of Tangier and the Atlantic and Mediterranean coasts. Transport infrastructure within and leading to the Tangier Peninsula has been extended, is under construction, or is being planned. This includes a regional airport, several motor ways and expressways, and new railway lines, including a high-speed rail TGV, in French parlance link to Casablanca. These Tangier-centered projects are embedded in larger programs, networks, and corridors pursued by a wide range of actors on and across different spatial scales. 


\section{Intervening Actors and Institutions}

First, various outside individual and institutional actors, with their respective interests, ideas, and strategies, intervene in the planning, financing, construction, and usage of diverse locally implanted projects.

At the national level, superordinate project planning and realization mostly fall to central government departments and their specifically established special agencies. ${ }^{4}$ In a kind of public-public partnership, such agencies group several state and para-state entities. Among them, the Agence pour la Promotion et le Développement économique et social des provinces du Nord (APDN, Agency for the Promotion and the Economic and Social Development of the Northern Provinces), under the direct control of the Prime Minister's office, gives financial and technical support to projects such as the Tanger Ville program, the TangerMed industrial and logistic platforms, and the high-speed rail link. The TangerMed Special Agency (TMSA) and its affiliates exercise state prerogatives in the planning, implementation, and management of the entire Tanger Méditerranée project. At the same time, the TMSA acts like a private company without the constraints of public administration, and represents several ministries including the APDN. Several state institutions also jointly own the Société d'Aménagement pour la Reconversion de la Zone Portuaire de Tanger Ville (SAPT, Planning Society for the Conversion of the Tangier City Port Zone), which is exclusively responsible for piloting the reconstruction of important inner-city areas surrounding the old port. In addition, further public development agencies are supporting and marketing several major investment projects for residential and tourism purposes. A young guard of highly educated technocrats with experience in private and international business is centrally placed in such public entities to implement the neoliberal, pro-business urban development agenda.

Beyond the spin-offs and partnerships of the public sector, we also observe an increasing shift of responsibilities and competencies for local projects and infrastructure to transnational and private actors. Affiliates of the above-mentioned agencies involve additional private companies. Internationally important operators, among them APM Terminals and Eurogate, have assumed the management of TangerMed container and oil terminals. The world's biggest container-shipping lines (such as Mærsk Line and CMA CGM), partially under the ownership of the same holding companies, are using the new port facilities to establish globally integrated transport networks. Foreign companies also control ferry services between Europe and the ports of the Tangier Peninsula. International planning and architecture offices, developers, and sales companies (notably of Spanish and 
Gulf Arab origin) design, build, and market exclusive tourism and real estate projects. To construct TangerTech City, the regional administration has established a joint venture with a major internationally operating Moroccan bank and a Chinese holding company.

In addition, several European, Euro-Mediterranean, African, and Arab regional organizations and development funds as well as national and subnational cooperation agencies from Western Europe, the Gulf states, and Japan provide financial support and planning expertise for numerous infrastructure projects. In particular, diplomatic representatives from the EU and its member states hold seats on the APDN's advisory board.

\section{Integrating Policies, Programs, and Infrastructure Networks}

The projects and programs for Tangier listed above are embedded in much larger and overlapping infrastructure schemes, development plans, and economic strategies conceived with various geographical reaches.

Hence, new infrastructure largely results from a number of national agendas to enhance the Moroccan transport systems by 2030 or 2040, such as several national highway initiatives that have been expanding since the mid-1990s; national programs to modernize the conventional rail network and to build a high-speed rail system; and, finally, a series of port extension and construction projects within the national port strategy. Overall, these plans and other projects fit into a wide range of mid- to long-term national development plans aimed at boosting logistical competitiveness, integrated industrial platforms, emerging industries, and notably trade and tourism.

In a wider context, Tangier's new infrastructural links are considered parts of transnational schemes and corridors established by regional institutions and arrangements in order to facilitate regional trade and mobility (Wippel 2012a; Fig. 3). Accordingly, infrastructure centering on Tangier immediately connects northward to the EU's expanding Trans-European Networks for multimodal sea, road, and rail transportation. In the context of the Euro-Mediterranean cooperation, these networks have already been extended southward with supplementary trans-Mediterranean transport links. Among them, the construction of the Rocade Méditerranéenne (National Route 16) from Tangier to the Algerian border was the EU's biggest infrastructure funding project outside Europe. At the same time, road and railway infrastructure integrates Tangier into trans-Maghrebian transport schemes adopted by the Arab Maghreb Union. Tangier also constitutes the north- 


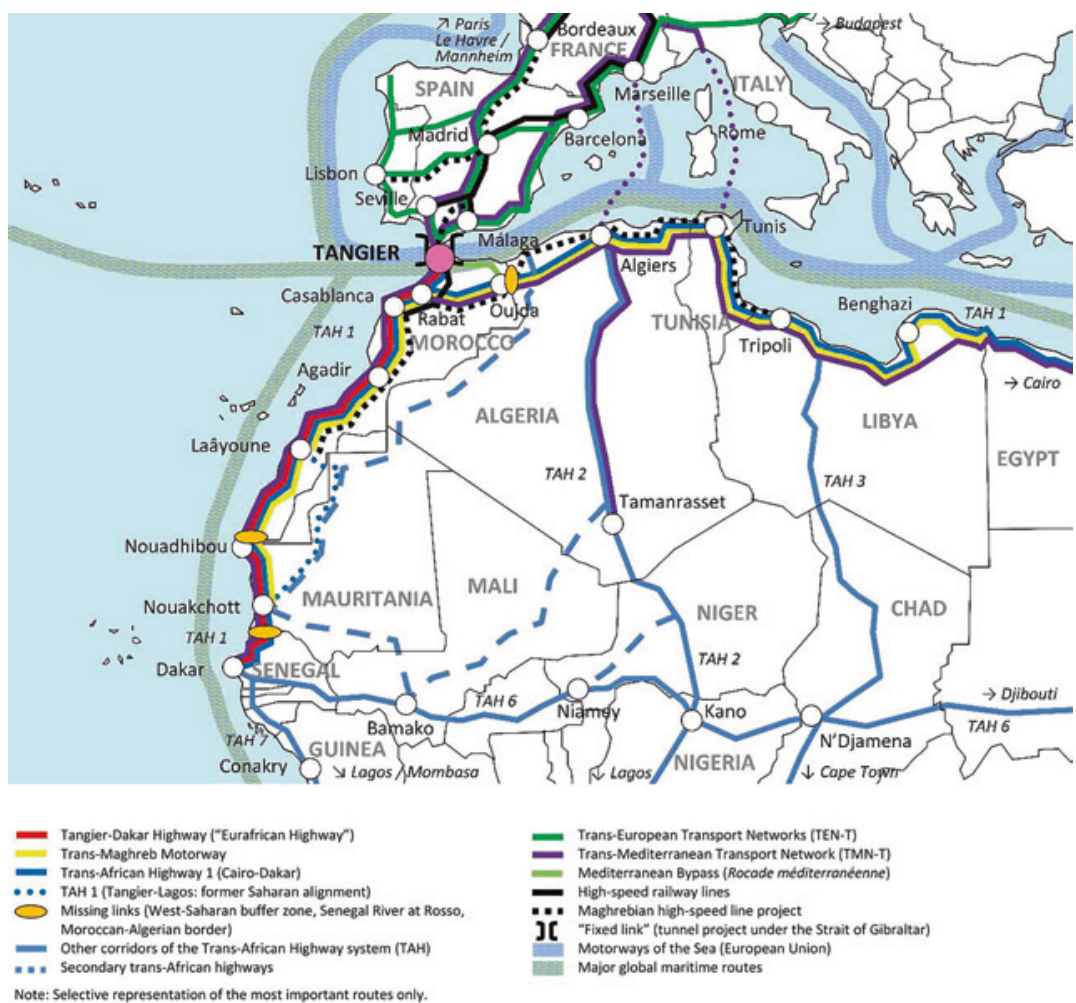

Fig. 3 Tangier at the Intersection of Multiregional Transport Systems; Concept and cartography: Steffen Wippel, 2019.

ernmost end of Pan-African traffic corridors, which converge towards the city along the Atlantic coast from the south and along the Mediterranean coast from the east. Notably, the Tangier-Dakar Highway integrates the larger Cairo-Dakar route and connects to further trunk-road projects in western Africa (cf. also Marfaing and Wippel 2005). Several bilateral as well as Mediterranean, African, and UN programs also include the long-planned tunnel across the Strait of Gibraltar to connect Tangier directly to Spain (cf. also Wippel 2000). Furthermore, Morocco intends to develop the Tangier Peninsula into an energy hub. The power lines and gas pipelines with Algeria and Spain connect to larger European grids and, in the future, are intended to integrate Pan-Arab, circum-Mediterranean, and West African networks. 
Last but not least, current development efforts, which open Tangier to international capital and spark far-reaching connections, are an excellently fit for larger national macro-policies related to foreign trade and regional integration (Wippel 2012a, 2012b). Hence, during the Euro-Mediterranean rapprochement in the 1990s, Morocco rediscovered its long-neglected "Mediterranean façade" (Zaïm 1990). Accordingly, the city's transformation integrates the government's endeavors for a privileged partnership with the EU. In parallel, the kingdom started to intensify its African policy, including a strengthened economic presence, notably in the field of strategic investment and firm cooperation. This is part of an institutional turn towards a "multidirectional regionalism" that allows for membership in several overlapping free-trade agreements and regional economic organizations and also includes enhanced transatlantic cooperation. Morocco's foreign trade relations, still very much concentrated on European markets, are likewise diversifying. These largely correspond to Tangier's developing links, presented in the next section, but are not fully congruent with them.

\section{Emerging Connections, Entanglements, and Flows}

Based on the current infrastructure megaprojects, Tangier has become a hub for important border-crossing entanglements and circuits of various scopes. Notably, the new TangerMed port promoted the deployment of new regional and transregional traffic flows. Starting from zero in 2007, ten years later 430 weekly shipping lines connected the existing container terminals with 174 other ports in 74 countries worldwide (Tanger Med Port Authority 2017; Fig. 4). Europe is still the most important destination, but now nearly a quarter of all connections lead to ports along Africa's Atlantic coast, from Mauritania to Angola; a decade ago, Morocco's lack of maritime links to sub-Saharan Africa was still frequently lamented (cp. Wippel 2012b, p. 1131 f.). The Mediterranean constitutes another regional focus, alongside further noteworthy links with the greater Middle East, Latin America, and southern and eastern Asia. In contrast, passenger traffic from Tangier travels nearly exclusively to European, and mainly Spanish, ports. The vehicle port terminal also ships cars as far as Brazil, South Africa, Japan, and Australia. Logistic firms at TangerMed primarily serve European markets but have also started to transport goods overland via the new road to West Africa.

More than six hundred foreign companies, among them internationally prestigious firms (such as Renault-Nissan, DHL, Lear, Huawei, Siemens, Danone, and Decathlon) have established a base in the TangerMed industrial and logistics platform. Most of these enterprises come from the European Union, with 


\begin{tabular}{|l|c|c|}
\hline Various regional delimitations & $\begin{array}{l}\text { Share in ports called } \\
\text { from/via Tangier }\end{array}$ & $\begin{array}{l}\text { Share in weekly } \\
\text { connections }\end{array}$ \\
\hline Europe & $34.4 \%$ & $45.3 \%$ \\
\hline Atlantic Europe & $13.2 \%$ & $16.4 \%$ \\
\hline Mediterranean Europe (incl. Black Sea) & $21.2 \%$ & $28.4 \%$ \\
\hline Arab world & $13.2 \%$ & $15.8 \%$ \\
\hline Maghreb & $4.6 \%$ & $5.6 \%$ \\
\hline Gulf states & $5.3 \%$ & $7.2 \%$ \\
\hline Atlantic Africa (incl. Mauritania) & $20.5 \%$ & $23.2 \%$ \\
\hline Mediterranean (incl. Black Sea) & $25.9 \%$ & $32.8 \%$ \\
\hline North America & $5.3 \%$ & $1.7 \%$ \\
\hline Latin America & $17.9 \%$ & $10.4 \%$ \\
\hline Atlantic America & $16.6 \%$ & $10.1 \%$ \\
\hline Asia (excl. Middle East) & $11.3 \%$ & $7.5 \%$ \\
\hline
\end{tabular}

Fig. 4 Container Shipping Links from TangerMed (Import and Export, June 2017); Source: TangerMed Port Authority 2017. Author's calculations.

more than one third being of Spanish origin, but there are also firms from the US, Arab states, and, more recently, China. From here, they are mostly exploring European and increasingly sub-Saharan and North African markets-such as the Renault-Nissan plant, which exports nearly its entire car production, mostly to European countries, but also to African and Arab countries. The new tourist infrastructure aims at attracting international visitors, especially from Europe, including Moroccans living abroad, and from Arab Gulf states (Berriane 2011). Correspondingly, with increasing attractiveness, international tourism figures in the Tangier region have increased steadily in recent years.

In addition, Tangier remains a central departure and transit point for intercontinental migration. Every year, about five million passengers to and from Europe, mostly Moroccan expatriates during the holiday season, cross the Tangier Peninsula. At the same time, the region has become an important transit hub for irregular migrants from Morocco, sub-Saharan Africa, and recently South Asia and the Middle East (e.g. Alioua 2007; Mouna 2016a, 2016b). Conversely, the economic crisis in their home country temporarily caused Spaniards to look for work in the boom town across the Strait. 
Besides being an established platform for the trade in cannabis from the nearby Rif Mountains, Tangier has become a hub for hard drugs arriving from Central Asia and Latin America and destined for European markets. ${ }^{5}$ In the other direction, the informal import of consumption goods from the nearby Spanish enclave of Ceuta constitutes another lucrative business, and the trans-Saharan road has given West African customers access to used European vehicles via Tangier.

\section{Strengthened Competition and Strategic Positioning}

In accordance with neoliberal logic, Tangier is being regarded primarily as an economic project and has entered fierce national, regional, and global competition with other places for port traffic, investment, tourism and overall attention, notably in the Western Mediterranean, but also on the African continent. Actors strategically exploit Tangier's exposed geographic position on the northernmost tip of Morocco and Africa at the edge of Europe as well as its location along the world's most important shipping lane, connecting East Asia through the Mediterranean and the Atlantic to the American East Coast. This motif of the city's advantageous location is repeatedly invoked in the multi-level branding of projects, firms, and the city. Responsible persons and institutions-from local authorities and associations, national tourism, and investment agencies to international companies and developers-explicitly emphasize Tangier's continuing role as a "gateway to Europe" as well as its emerging position as a "gateway to Africa."

The TangerMed container port rapidly became the busiest Moroccan harbor. It is about closing ranks with Algeciras, a regional forerunner of container transshipment at the opposite side of the Gibraltar Strait, and has now advanced to rank 46 worldwide in annual throughput (Lloyd's List 2018, p. 12; Fig. 5). In 2017, it was the busiest container port in all Africa and the fourth in both the MENA region and in the Mediterranean. It will be the largest port in the Mediterranean region after completion of phase II. The opening of the new terminals will push the port to the Top 20 worldwide compared with current volumes. Also, the world's biggest shipping lines have made Tangier a major hub in their global networks; for example, CMA CGM uses it this way for its Euro-African 


\begin{tabular}{|l|l|l|l|l|l|l|}
\hline $\begin{array}{l}\text { World } \\
\text { rank }\end{array}$ & $\begin{array}{l}\text { Annual } \\
\text { change } \\
\text { of } \\
\text { position }\end{array}$ & Port & Country & Region & $\begin{array}{l}\text { Annual } \\
\text { throughput } \\
(1,000 \text { TEU) }\end{array}$ & $\begin{array}{l}\text { Annual \% } \\
\text { change }\end{array}$ \\
\hline 1 & - & Shanghai & China & Asia & & \\
\hline 9 & - & Dubai & UAE & MENA & 40,233 & $+8.3 \%$ \\
\hline 29 & - & Valencia & Spain & Mediterranean & 4,832 & $+2.1 \%$ \\
\hline 34 & -6 & Algeciras & Spain & Mediterranean & 4,390 & $-7.8 \%$ \\
\hline 36 & +1 & Jeddah & Saudi & MENA & 4,150 & $+4.9 \%$ \\
\hline 37 & +1 & Piraeus & Greece & Mediterranean & 4,145 & $+10.9 \%$ \\
\hline 39 & +1 & Salalah & Oman & MENA & 3,946 & $+18.7 \%$ \\
\hline 46 & +5 & TangerMed & Morocco & Mediterranean/ & 3,312 & $+11.7 \%$ \\
\hline 50 & -3 & Marsaxlokk & Malta & Mediterranean & 3,150 & $+2.1 \%$ \\
\hline 51 & +3 & Ambarli & Turkey & Mediterranean/MENA & 3,132 & $+11.9 \%$ \\
\hline 55 & +19 & Barcelona & Spain & Mediterranean & 2,969 & $+32.7 \%$ \\
\hline 56 & -7 & Port Said & Egypt & MENA/Africa & 2,968 & $-2.2 \%$ \\
\hline 66 & -3 & Durban & $\begin{array}{l}\text { South } \\
\text { Africa }\end{array}$ & Africa & 2,700 & $+3.1 \%$ \\
\hline & & & & & \\
\hline
\end{tabular}

Fig. 5 TangerMed in the Global and Regional Port Hierarchy (2017); TEU: twenty feet equivalent unit (standard container). Note: Ports with annual throughput greater than 2.7 million TEU. Source: Lloyd's List 2018, p. 12 f.

connections. Simultaneously, this has contributed to a great increase in Morocco's global connectivity. ${ }^{6}$ Tangier now hosts Africa's biggest car production plant, and its large free zone was recently rated the most competitive on the continent (fDi 2015). The agglomeration, with about one million inhabitants, has become Morocco's second economic pole, and the World Bank (2015) listed Tangier as one of six model cities for economic growth and competitiveness in the "Global South." Among African cities, Tangier received the third-most foreign direct investment (FDI) and experienced the fourth-highest FDI growth in the years 2003-16 (UN-Habitat and IHS 2018, p. 45 ff.). 


\section{Increasing Fragmentation, Territorialization, and Other Problems}

However, Tangier's current development increasingly exhibits problematic aspects. Not all projects have been completed on schedule, and many are still in the planning stages. Harsh political realities, notably international conflicts and issues of security and migration, have impaired many transport schemes. Other projects face geophysical and financial challenges. From international trade to tourism, current strategies involve sectors reacting rather sensitively to political and economic crises elsewhere in the world and to fierce competition from other emerging places. For example, political and economic calamities in the investors' home countries, such as Spain and the Gulf, have delayed several tourism and real-estate projects.

Some of the major local consequences of these new outward-oriented mega-projects and entanglements have included the reinforcement of territorial and socioeconomic fragmentation inside the urban agglomeration. Thus, the new port and export-oriented free zones are typical examples of locally disembedded fragments that are much more closely connected to international economic hubs and circuits than to their immediate urban and national hinterlands. Accordingly, about 95 percent of the container throughput at TangerMed is pure transshipment between different container vessels, one of the highest shares worldwide. The free zones, too, predominantly work on an import-export basis, and interlinkages with the local and national economies are developing only gradually.

The institutions established by the central state have far-reaching executive (and even legislative) powers over important areas of the metropolitan area to the detriment of local competencies, interests, and needs. This is despite a process of "advanced regionalization" adopted in recent years to devolve more decision-making power to subnational entities. The TMSA alone was allotted a 550 square-kilometer special zone near the port for infrastructural extension and socio-economic development (Fig. 1). Similarly, the SAPT has at its disposal a contiguous planning area in the city center, where it can act mostly autonomously (Fig. 6). At the same time, the numerous megaprojects are characterized by an "ad-hoc urbanism," with project-related master plans largely overruling comprehensive and structured urban planning.

The projects also have led to the spread of territorial exclaves across the peninsula. Large sites like the TangerMed port complex, the special economic zones, gated communities, and all-inclusive tourism complexes are surrounded by walls and fences, accessible only through guarded gates or with special permits. They 

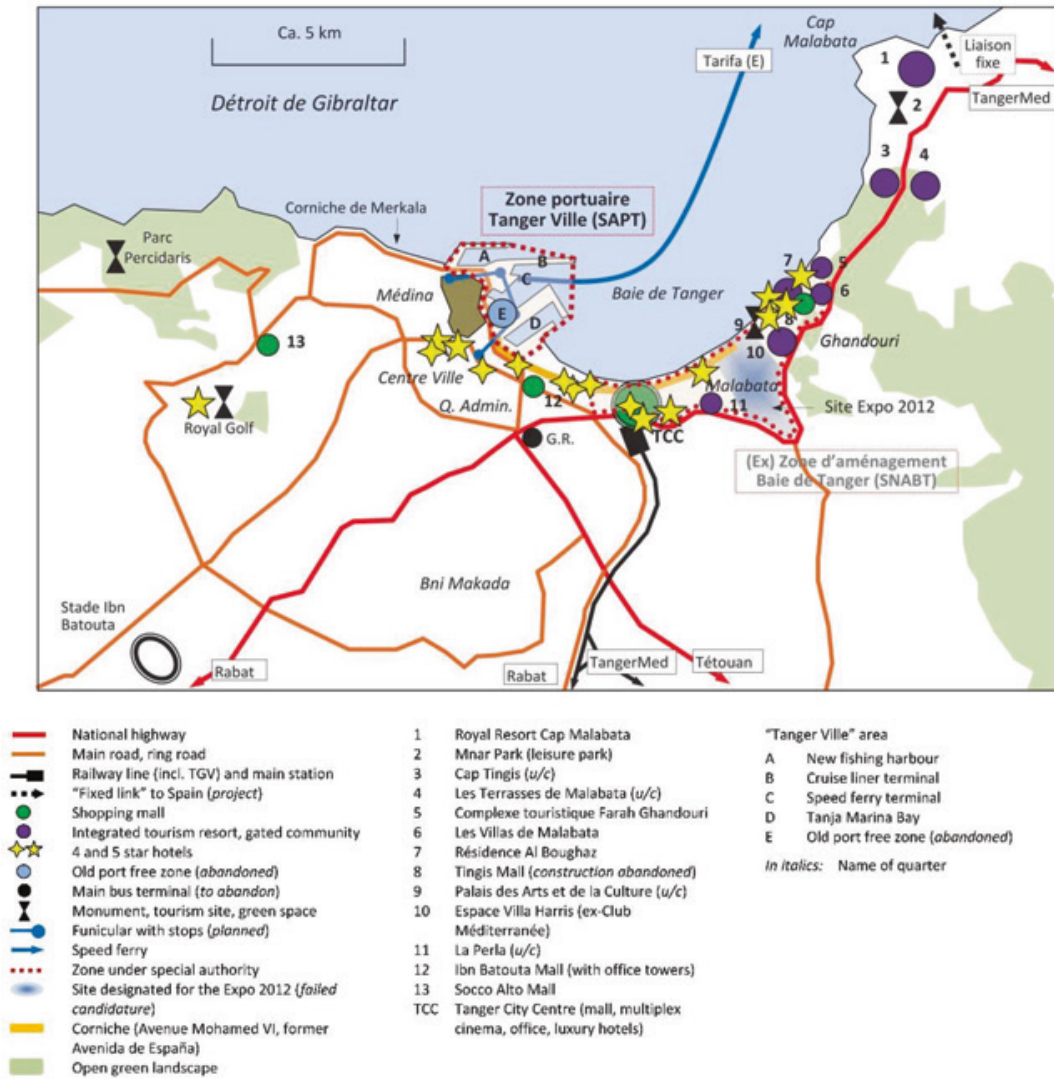

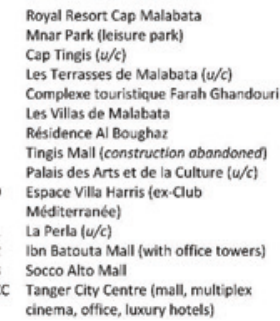

Fig. 6 Major Urban Projects in the Inner City of Tangier since the Late 2000s; Concept and cartography: Steffen Wippel, 2018.

block access to hitherto open spaces, like formerly popular beaches and agricultural land. Other projects, such as the new shopping malls and the upgraded old port district with its marina, luxurious residences, shopping, and leisure facilities, are under private control. Large portions of society simply cannot afford to take advantage of them-despite repeated public declarations aiming to "return the sea to the city."7

Workplaces in central parts of the city have been displaced to the periphery or replaced by highly automated processes. This also creates huge transport 
problems. Simultaneously, in the medina, gentrification has set in as more and more wealthy foreigners settle there (Chattou 2011; Peraldi 2007, p. 116). Meanwhile, the established population does not benefit much from increasing cruise tourism based in the old city's adjacent port. Consequently, large segments of the local society do not seem to be benefiting sufficiently from the current processes, and even its elites feel excluded from the current planning processes and development opportunities.

It is therefore unsurprising that the tendency to ignore local concerns and social needs, even while integrating the city regionally and globally, has triggered repeated protests over the last decade, from demonstrations against land expropriation, socio-ecological impacts and working conditions related to the new port (Mareï 2012, p.7 f.; Planel 2011; Barthel and Planel 2010) to protests against the high building costs of the high-speed rail line (Lahlou 2016) and the displacement of firms from the inner city. Therefore, it is probably no coincidence that, two years after the 2011 demonstrations, the king announced the Tanger Métropole program, which focuses much more on local progress than the more prominent mega-projects did.

\section{Conclusion: Re-Configurations of an Emerging "Secondary City" with Transregional Links, Embedded in Multiple Scales}

Purposefully "developing" Tangier is part of a long-term strategy which started at the turn of the millennium and integrates much wider national, regional, and global re-configurations. The advancement of some projects was impacted by the 2008-09 international financial and economic crisis, mostly due to its effects on partners' countries, notably in the tourism and real estate sectors. This effect was much more visible than that of the politically and socially motivated demonstrations in 2011 and the years after, despite strong participation of the local population. These events did not fundamentally alter the Moroccan political system, including the opaque dual structure of official state administration and the parallel makhzen system surrounding the royal court. Compared to pre-2011 Tunisia, for example, Moroccan authorities already had retained more power on project execution in relation to Gulf investors and paid more attention to the local contextualization of megaprojects (Barthel 2014). But since then, more formal civil society participation in urban development has not really come about. In fact, a series of centrally installed project agencies is still shaping pivotal urban and infrastructural developments, catering the interests of global actors as well as 
transnationally oriented middle- and upper-class segments of the national society. As Beier (2016) demonstrated, Tunisia turned to more inclusive urban development strategies after the events of 2011, whereas Morocco remains caught in the dilemma between the megaproject based creation of world-class cities and a counteractive "urbanism of urgency" for the urban peripheries. Consistently, in Tangier, large-scale projects still dominate (or at least shape the cityscape) while targeted small-scale interventions remain too tentative and are generating insufficient results. Nevertheless, the 2013 Tanger Métropole program can be interpreted as one conciliatory response to widespread discontent in the city.

Conceptually, there are various ways to grasp the current development of a city such as Tangier. This chapter shows that, first, like many MENA cities, Tangier has experienced significant neoliberal development (e.g. Heeg 2019; Al-Hamarneh et al. 2019). This extends beyond pure laissez-faire liberalism, which would leave urban development exclusively to the private sector, as indeed happened during the International Zone period (Nieto and El Idrissi 2009). Instead, state institutions have strongly committed to developing a competitive, outward-oriented city, to following the logic of the market, and to actively laying the groundwork for the strong involvement of global firms. Extended islands of neoliberal transformation and postmodern development have at the very least penetrated the agglomeration and are contributing to a "splintering urbanism" (Graham and Marvin 2009). This goes along with additional postmodern endeavors to attract worldwide attention through distinguished landmarks and extensive marketing (Soja 2000).

Second, it is not only established and emerging "global cities" (Sassen 1991) or "world cities" (Friedmann 1986) that achieve central positions in global networks. Tangier is not yet included in this new meta-geography of global cities, and it is even not listed in the most inclusive of such rankings (GaWC 2018). But even such a "secondary city" by national, regional, and global standards is intensively globalizing and neoliberalizing, increasingly integrating far-reaching networks, and occupying a central position in specific circuits, for example as a major transshipment hub in maritime world trade. ${ }^{8}$ Moreover, we find characteristics of contemporary port city development, with the main port activities shifting outside the city proper, whereas the old port's premises are undergoing exclusive waterfront development and upgrading (Hoyle 2000). Tangier also exhibits some specific features of a border city, formerly between different colonial zones and today between states, continents, and institutionalized regional blocks. It therefore confronts all the challenges, opportunities, and obstacles such a border position entails for human and material mobility and urban and economic development (e.g. Sohn and Licheron 2015). Accordingly, these borders act as barriers and impediments 
to human and material cross-border flows and, in the past, they exacerbated socioeconomic marginalization and political neglect. But, at the same time, the border situation has lent itself to creative exploitation for establishing (formal and informal) types of mobility and exchange and for fostering economic progress as a showcase to the outside world and a gateway for border-crossing connections (see also Flynn 1997; Becker 2005). It can also be used for branding the city to the wider world to attract visitors, investors, and others.

While the multiple facets of urban development require a multi-conceptual approach, they all show important spatial dimensions. Consequently, the focus here has been on a spatial perspective. In this regard, from an urban perspective, "globalization" does not mean that the city is equally connected to all parts of the world. Rather, we observe regional densifications of contacts and exchange. Tangier is often placed into spatial containers such as the nation-state and the Maghreb, Arab, or MENA world regions. Accordingly, it has developed a multitude of translocal, transnational, and transregional links that transgress the established spatial configurations and segmentations that are widespread in the political, academic, and public realms. ${ }^{9}$ Indeed, based on material infrastructures and actors' strategies, Tangier's own city-centered regionalizations have emerged. They mostly display rhizomatic and archipelago-like (Veltz 1996) forms with fuzzy limits and oscillating extensions along threadlike lines of transport and mobility, connecting to other specific places and hubs, rather than corresponding to spatially and temporally contiguous areas. Conversely, these links transgressing urban and other borders are not developed from all places in the city equally. Rather, heavily globalized—or better, "regionalized"-enclaves are intensively linked to the "outside world," specifically other global places and regional hubs. This kind of uneven urban development creates severe spatial fragmentation across the cityscape, while participating in a "fragmented globalization" reproduced across several spatial levels from the local to the global scale (Scholz 2004, p. 221 ff.; see also Robinson 2002).

Finally, this chapter has also demonstrated that actors, infrastructures, programs, flows, networks, and positions on different scales are what make and shape the city:

1. Individual and institutional actors from several spatial levels intervene, pursue their policies and strategies, and contribute to the city's development, often bypassing local interests and competencies.

2. Tangier's local infrastructure and urban development is integrated into much wider and overlapping schemes, programs, visions, plans, and policies conceived on several spatial scales and with different geographical reaches. 
3. Tangier has become a hub for important trade, transport, investment, tourism, and migration flows that crisscross national, macro-regional and global levels, in trans-Mediterranean and trans-Saharan North-South directions as well as along a maritime East-West axis.

4. Finally, this positions Tangier in several regional and global networks of places in close cooperation as well as fierce competition, making purposive use of its location, and emphasized by diverse rankings and strategic communication alike.

In sum, there is an important multi-scale dimension in Tangier's current urban re-configuration with interventions, connections, and repercussions that jump across scales. Like regions, scales are socially constructed. This entails a continuous rescaling of relevant actors, activities, and flows as well as competencies, responsibilities, and effects. But as transnational actors act on a local level, cities form direct regional networks beyond territorial hierarchies. At the same time, locally oriented measures push transregional infrastructures and mobilities (cf. Sassen 2003). Thus, different scales are not sharply separated, but increasingly interpenetrate, progressively blur, and become difficult to distinguish analytically. ${ }^{10}$ Hence, although Brenner's focus (e.g., 1997) is still primarily on global metropolises, he understands cities in the course of continuous reterritorialization and rescaling processes as interfaces between multiple, overlapping spatial scales.

In the end, a predominantly spatial perspective on Tangier's current re-configurations is more than an academic exercise. It reflects important political, social, and economic processes that take shape through several spatial scales and embed Tangier within multi-scalar networks.

\section{Endnotes}

1. This observer perspective may considerably contrast with actors' normatively loaded visions of linear growth and unidirectional development. But as the terminology blurs, I also employ "urban development" and similar terms in the following. I understand them, like in most social and cultural disciplines today, as a non-linear and non-teleological process of recurrent transformation, re-configuration, change and evolution covering a broad range of closely interrelated material and societal aspects.

2. For information that is more comprehensive and more details on Tangier, cf. Tafersiti Zarouila 2012; Haller et al. 2016; Haller 2016; Wippel 2019 in the following.

3. One of the two new terminals opened in June 2019 disposing of an annual capacity of 5 million containers; the second will follow in late 2020. 
4. On the general "agencification" of urban development in Morocco, cf. Amarouche and Bogaert 2019; on planning policies in Tangier, Kanai and Kutz 2013; Planel 2011.

5. For the development of manifold informal flows, cf., for instance, Abderrahmane 2013; Mouna (2016b); Peraldi 2007.

6. According to the UNCTAD's global connectivity index, Morocco advanced from place 78 (2004) to 16 (2014). Cf. UNCTAD: Liner shipping connectivity index, annual, 2004-2016. https://unctadstat.unctad.org/wds/ TableViewer/tableView.aspx?ReportId=92. Accessed: 13 Feb 2016.

7. Tanja Marina Bay International. Reconversion du port: Objectifs. https:// www.tanjamarinabay.ma/fr/presentation-projet-reconversion/. Accessed: 16 April 2019.

8. The term was first introduced by Rondinelli 1983. Cf. also, e.g., Roberts and Hohmann 2014; on "ordinary cities", Robinson 2002; on "globalizing cities", Marcuse and van Kempen 2000.

9. On the transregional transgression of such "meta-geographies", cf. Lewis and Wigen (1997); in the MENA region, Wippel and Fischer-Tahir (2018); on translocal entanglements, Freitag and von Oppen (2010).

10. This aspect was intensely discussed at a conceptual workshop on "Re-configuring Space and Representations: Theoretical approaches, empirical findings, conceptual reflections" of the research network in December 2017.

\section{References}

Abderrahmane, Abdelkader. 2013. Drug trafficking in Northwest Africa: The Moroccan Gateway. Jadaliyya. https://www.jadaliyya.com/pages/index/15520/drug-trafficking-innorthwest-africa_the-moroccan. Accessed 8 Apr 2016.

Al-Hamarneh, A., J. Margraff, and N. Scharfenort, Eds. 2019. Neoliberale Urbanisierung: Stadtentwicklungsprozesse in der arabischen Welt. Bielefeld: transcript.

Alioua, M. 2007. Nouveaux et anciens espaces de circulation internationale au Maroc: Les grandes villes marocaines, relais migratoires émergents de la migration transnationale des Africains subsahariens au Maghreb. Revue des Mondes Musulmans et de la Méditerranée 119-120: 39-58.

Amarouche, M., and K. Bogaert. 2019. Reshaping space and time in Morocco: The agencification of urban government and its effects in the Bouregreg Valley (Rabat/Salé). Middle East - Topics \& Arguments 12 (1): 44-54. https://meta-journal.net/article/ view/7934/7875. Accessed 19 July 2019. 
Barthel, Pierre-Arnaud. 2014. Global waterfronts in the Maghreb: A mere replication of Dubai? Case studies from Morocco and Tunisia. In Under construction: Logics of Urbanism in the Gulf Region, ed. S. Wippel, K. Bromber, C. Steiner, and B. Krawietz, 247-258. Farnham and Burlington: Ashgate.

Barthel, P.-A., and S. Planel. 2010. Tanger-Med and Casa-Marina, prestige projects in Morocco: New capitalist frameworks and local context. Built Environment 36 (2): 176-191.

Becker, Franziska. 2005. Die Grenzstadt als Laboratorium der Europäisierung. In Die Wirklichkeit der Städte, ed. H. Berking and M. Löw, 87-105. Baden-Baden: Nomos.

Beier, Raffael. 2016. Shifting urban policies in North Africa after the "Arab Spring": Urgent reaction or real changes? Berlin: Klaus Schwarz.

Benabad, Driss. 2012. Projet de reconversion de la zone portuaire de Tanger Ville. Portus 24: 58-63. https://retedigital.com/wp-content/themes/rete/pdfs/portus/portus_24/Projet_de_reconversion.pdf. Accessed 13 May 2017.

Berriane, Mohamed. 2011. Profil de durabilité dans quelques destinations touristiques méditerranéennes: La destination du littoral de Tétouan au Maroc. Sophia Antipolis: Plan Bleu, Centre d'Activités Régionales PNUE/PAM. https://planbleu.org/sites/default/ files/publications/littoral_tetouan_maroc_berriane_2011.pdf. Accessed 17 Oct 2017.

Brenner, N. 1997. Globalisierung und Reterritorialisierung: Städte, Staaten und die Politik der räumlichen Redimensionierung im heutigen Europa. WeltTrends 17: 7-30.

Chattou, Z. 2011. Tanger à la croisée de nouvelles recompositions territoriales et de mobilités transnationales. Méditerranée 116: 133-138. https://mediterranee.revues.org/5447. Accessed 3 Nov 2016.

Ducruet, C., F. Z. Mohamed-Chérif, and N. Cherfaoui. 2011. Maghreb port cities in transition: The case of Tangier. Portus Plus 1(1): 60-67. https://www.reteonline.org. Accessed 8 June 2012.

fDi. 2015. Global free zones of the year 2015: Winners. fDi Intelligence, 12-37. https:// www.fdiintelligence.com/content/download/62195/1757464/version/2/file/GFotY_ FDI_1015.pdf. Accessed 30 Oct 2015.

Flynn, D.K. 1997. "We are the border." Identity, exchange, and the state along the Benin-Nigeria border. American Ethnologist 24 (2): 311-330.

Freitag, U., and A. von Oppen, Eds. 2010. Translocality: The study of globalising processes from a southern perspective. Leiden: Brill.

Friedmann, J. 1986. The world city hypothesis. Development and Change 17: 69-83.

GaWC. The world according to GaWC 2018. Globalization and World Cities Research Network, Loughborough University. https://www.lboro.ac.uk/gawc/world2018.html. Accessed 1 Feb 2019.

Graham, Stephen, and S. Marvin. 2009. Splintering urbanism: Networked infrastructures, technological mobilities and the urban condition. Reprint. London: Routledge.

Haller, Dieter. 2016. Tanger: Der Hafen, die Geister, die Lust. Eine Ethnographie. Bielefeld: transcript.

Haller, D., S. Wippel, and H. Reifeld (eds.). 2016. Focus sur Tanger: Là où l'Afrique et l'Europe se rencontrent. Rabat: KAS. https://www.kas.de/wf/doc/kas_46222-1522-330.pdf?160829112116. Accessed 24 Oct 2018.

Heeg, S. 2019. Neoliberalism and neoliberalization: Helpful devices for the analysis of urban development in the Middle East and North Africa. Middle East - Topics \& Arguments 12 (1): 19-26. https://meta-journal.net/article/view/7834/7881. Accessed 19 July 2019. 
Hoyle, B. 2000. Global and local change on the port-city waterfront. Geographical Review 90 (3): 395-417.

Kanai, M., and W. Kutz. 2013. Entrepreneurial assemblages from off the map: (Trans) national designs for Tangier. Environment and Planning D: Society and Space 31: 80-98.

Lahlou, Mehdi. 2016. Le Maroc et la ligne à grande vitesse. In Focus sur Tanger: Là où l'Afrique et l'Europe se rencontrent, ed. D. Haller, S. Wippel, and H. Reifeld, 163-178. Rabat: KAS.

Lewis, Martin W., and K. Wigen. 1997. The myth of continents: A critique of metageography. Berkeley: University of California Press.

Lloyd's List. 2018. One Hundred Ports 2018. No place: Maritime intelligence informa. https://transportationstore.informa.com/wp-content/uploads/woocommerce_ uploads/2018/09/LL-Top-Ports-sampler.pdf. Accessed 15 Apr 2019.

Marcuse, P., and R. van Kempen (eds.). 2000. Globalizing cities: A new spatial order? Oxford and Malden: Blackwell.

Mareï, Nora. 2012. Le détroit de Gibraltar dans la mondialisation des transports maritimes. EchoGéo 19. https://echogeo.revues.org/12919. Accessed 22 Oct 2015.

Marfaing, L., and S. Wippel. 2005. Die Öffnung der Landverbindung Dakar-Tanger und die Wiederbelebung transsaharischer Bewegungen. Comparativ 15 (4): 109-140.

Mouna, Khalid, Ed. 2016a. Espace imaginé, espace vécu et espace négocié: Parcours croisés des migrations espagnoles et subsahariennes à Tanger. Rabat: AMERM. https:// amerm.ma/wp-content/uploads/2016/05/Espace-imagin\%C3\%A9-espace-v\%C3\%A9cuet-espace-n\%C3\%A9goci\%C3\%A9-Mouna-Khalid.pdf. Accessed 28 Sept 2016.

Mouna, K. 2016b. Borders, drugs and migrants in Northern Morocco. Perspectives Middle East \& North Africa 10: 49-52. https://www.boell.de/sites/default/files/2016-10-perspectives_middleeast_10_borders.pdf. Accessed 31 Oct 2016.

Nieto, A. B., and A. El Idrissi. 2009. Tanger, croissance urbaine d'une ville internationale. In De l'opportunité d'un observatoire de la Medina, Ed. Al Boughaz, 49-60. Actes du séminaire, Tanger, 30 May 2009.

Peraldi, M. 2007. Economies criminelles et mondes d'affaire à Tanger. Cultures \& Conflits 68: 111-125. https://conflits.revues.org/pdf/5973. Accessed 2 Nov 2017.

Planel, S. 2011. Mobilisations et immobilisme dans l'arrière-pays de Tanger-Med: Effet des contradictions de la réforme de l'État. Revue Tiers Monde HS 5: 189-206.

Roberts, Brian Herbert, and R. P. Hohmann. 2014. The systems of secondary cities: The neglected drivers of urbanising economies. Brussels: CIVIS. https://www.citiesalliance.org/sites/citiesalliance.org/files/CIVIS\%20SECONDARY\%20CITIES_Final.pdf. Accessed 12 Aug 2015.

Robinson, J. 2002. Global and world cities: A view from off the map. International Journal of Urban and Regional Research 26 (3): 531-554.

Rondinelli, Dennis A. 1983. Secondary cities in developing countries: Policies for diffusing urbanization. Beverly Hills: Sage.

Sassen, Saskia. 1991. The global city: New York, London, Tokyo. Princeton and Oxford: Princeton University Press.

Sassen, Saskia. 2003. Globalization or denationalization? Review of International Political Economy 10 (1): 1-22.

Scholz, Fred. 2004. Geographische Entwicklungsforschung: Methoden und Theorien. Berlin and Stuttgart: Gebrüder Borntraeger. 
Sohn, Christophe, and J. Licheron. 2015. From barrier to resource? Modelling the border effects on metropolitan functions in Europe. Working paper 2015-08. Luxembourg: LISER.

Soja, Edward W. 2000. Postmetropolis: Critical studies of cities and regions. Oxford: Blackwell.

Stuart, Graham H. 1955. The international city of Tangier. Stanford: Stanford University Press.

Tafersiti Zarouila, Rachid. 2012. Tanger: Réalités d'un mythe. Le mythe résiste. Tangier: Zarouila.

Tanger Med Port Authority. 2017. Maritime connections June 2017. Oued R'mel: TMPA. https://www.tmpa.ma/wp-content/uploads/2017/08/Livret-connexions-maritimesJuin-2017-1.pdf. Accessed 5 Sept 2017.

UN-Habitat and IHS-Erasmus University Rotterdam. 2018. The state of African cities 2018: The geography of African investment. Nairobi: UN-Habitat.

Veltz, Pierre. 1996. Mondialisation, villes et territoires: l'économie d'archipel. Paris: Presses Universitaires de France.

Wippel, S. 2000. Die "feste Verbindung" mit Europa: Infrastrukturprojekte über die Straße von Gibraltar und ihre symbolische Bedeutung für die regionalen Zugehörigkeiten Marokkos. asien afrika lateinamerika 28 (6): 631-676.

Wippel, S. 2012. Wirtschaft, Politik und Raum: Territoriale und regionale Prozesse in der westlichen Sahara. Berlin: Hans Schiler.

Wippel, S. 2012. Marokko in globalen und regionalen grenzüberschreitenden Handelsströmen. In Alltagsmobilitäten: Aufbruch marokkanischer Lebenswelten, ed. I. Breuer and J. Gertel, 241-265. Bielefeld: transcript.

Wippel, S. 2019. Stadtentwicklung in Tanger (Marokko): Rekonfigurationen des Urbanen im neoliberalen Kontext. In Neoliberale Urbanisierung: Stadtentwicklungsprozesse in der arabischen Welt, ed. A. Al-Hamarneh, J. Margraff, and N. Scharfenort, 33-73. Bielefeld: transcript.

Wippel, S., and A. Fischer-Tahir, Eds. 2018. Jenseits etablierter Meta-Geographien: Der Nahe Osten und Nordafrika in transregionaler Perspektive. Baden-Baden: Nomos.

World Bank. 2015. Competitive cities for jobs and growth: What, who, and how. Washington, DC: The World Bank Group. https://www-wds.worldbank.org/external/default/ WDSContentServer/WDSP/IB/2015/12/08/090224b083c371d5/2_0/Rendered/PDF/ Competitive0ci000what00who00and0how.pdf. Accessed 2 Feb 2016.

Zaïm, Fouad. 1990. Le Maroc et son espace méditerranéen: Histoire économique et sociale. Rabat: Confluences.

Steffen Wippel was a researcher at the research network "Re-Configurations" at PhilippsPhilipps-Universität Marburg (Germany) until January 2019, and currently is an associate researcher with the Center for Near and Middle Eastern Studies at that same university. $\mathrm{He}$ studied economics and Islamic studies in Freiburg i.Br. and Aix-en-Provence, holds a PhD from Freie Universität Berlin and a habilitation degree from Universität Erlangen-Nürnberg (Germany). His research focuses on processes of regionalisation, including a transregional perspective, and contemporary urban development in the MENA region. 
Open Access This chapter is licensed under the terms of the Creative Commons Attribution 4.0 International License (http://creativecommons.org/licenses/by/4.0/), which permits use, sharing, adaptation, distribution and reproduction in any medium or format, as long as you give appropriate credit to the original author(s) and the source, provide a link to the Creative Commons license and indicate if changes were made.

The images or other third party material in this chapter are included in the chapter's Creative Commons license, unless indicated otherwise in a credit line to the material. If material is not included in the chapter's Creative Commons license and your intended use is not permitted by statutory regulation or exceeds the permitted use, you will need to obtain permission directly from the copyright holder.

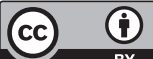

